\title{
On the need for independently estimating organic tripton carbon content
}

\author{
P. Pissierssens, M. Bergmans \& Ph. Polk \\ Ecology and Systematics Laboratory, Vrije Universiteit Brussel, Pleinlaan 2, B-1050, Brussel, Belgium
}

\begin{abstract}
A method is described by which the contribution of Non-Living Particulate Organic Matter (NLPOM) to Total Organic Matter can be determined. The dye Trypan Blue stains only dead organic matter. The surface of the stained particles is used as an indirect measure of the NLPOMcarbon content. Applying this method, it is shown that the bivariate linear regression of POM on chlorophyll a may produce serious errors in the calculated NLPOM contribution when carbon which is neither tripton- nor chlorophyll-related is present in appreciable quantities.
\end{abstract}

\section{INTRODUCTION}

In the euphotic zone, Non-Living Particulate Organic Matter (henceforth NLPOM) is usually determined by calculating the difference between TPOM (Total Particulate Organic Matter) and Living Particulate Organic Matter. The latter is calculated by multiplying the ATP-content, chlorophyll a content, or cell count by a conversion factor (Hagmeier 1961, Strathmann 1967, Gassmann \& Gillbricht 1982). This method has several disadvantages, all related to the determination of the 'Living Carbon' (Banse 1977). The carbon to chlorophyll ratio is not a constant factor in living cells; neither is the cell volume to cell carbon ratio. There are individual (Laws \& Wong 1978), speciesspecific (Chan 1978), diurnal (Laws \& Wong 1978), and possibly geographical and seasonal variations. Since the ATP-content of a cell is influenced by the physiological condition of the cell, the ATP to carbon ratio is variable as well (Mel'nikov 1976). All these problems and drawbacks make the calculated Living Carbon, and therefore also the NLPOM data, rather imprecise. To compound the problem, the assumption that NLPOM equals TPOM minus chlorophyll-related $C$ is not always justified.

For this reason, we here propose a new method involving the vital stain Trypan Blue. This dye makes it possible to distinguish between living and dead particulate organic matter. Though the method does not by itself yield a quantitative measure of NLPOM in terms of carbon, an empirical conversion factor is easily obtained when enough samples containing the same type of tripton are available.

\section{MATERIAL AND METHODS}

In our procedure we use the vital stain Trypan Blue. This dye, which is widely used in animal cytology, has the interesting property of staining proteins in dead cells or particles only. For our purpose we have modified the original recipe published by Phillips (1973) as follows. To obtain $100 \mathrm{ml}$ solution, $0.4 \mathrm{~g}$ Trypan Blue, $0.81 \mathrm{~g} \mathrm{NaCl}$ and $0.6 \mathrm{~g} \mathrm{KH}_{2} \mathrm{PO}_{4}$ are dissolved in distilled water. After boiling and cooling, the $\mathrm{pH}$ is adjusted to 7.2 using $\mathrm{NaOH}$. To stain the NLPOM (or rather its proteins), $10 \mathrm{ml}$ of this solution is added to a sample of about $100 \mathrm{ml}$. After $5 \mathrm{~min}$ the mixture is filtered on a 47 $\mathrm{mm}$ Whatman GF/C glassfiber filter which is afterwards rinsed with filtered seawater. The filters may then be preserved in a freezer in a Millipore Petrislide $(47 \mathrm{~mm})$.

For determination of total NLPOM surface area, the outline of each particle is drawn using a light microscope with a camera lucida. Calculation of the surface areas is performed using an Apple II graphics tablet, coupled to an Apple II microcomputer. The program which we used not only calculates the surface area of the particles, but also the equivalent circular diameter and, furthermore, produces histograms of surface and diameter distributions

For determination of chlorophyll a content, replicate 
samples were filtered on Whatman GF/C glassfiber filters. Chlorophyll was extracted with $90 \%$ acetone. After centrifugation, the extract was measured spectrophotometrically. Calculations were made using the Strickland \& Parsons (1968) formula. Total Particulate Organic Carbon (TPOC) was measured with a Coulomat 701 Carbon Analyser.

The total NLPOM surface area is used as an indirect measure of the NLPOM-carbon content. This measure, together with chlorophyll $a$ and TPOC, may be fed into a multiple linear regression program with TPOC as the dependent variable. This produces a regression formula of the form:

$$
\begin{gathered}
\mathrm{TPOC}=\text { constant }+\mathrm{A}(\text { chlorophyll } a) \\
+\mathrm{B}(\mathrm{NLPOM})
\end{gathered}
$$

where $\mathrm{B}(\mathrm{NLPOM})=$ NLPOM carbon of interest. Using this formula, one also obtains an empirical estimate of the specific carbon content of the phytoplankton, viz. the A-factor. When there is no zooplankton present, the constant should theoretically equal zero. As will be seen in the results, however, this is not always true.

\section{RESULTS}

We have tested the method on 3 sets of samples: 2 from the Belgian coastal zone (Jun and Nov 1983) and 1 from the French coastal zone near Boulogne (Apr 1983). Bivariate relations were estimated using linear regression. In Table 1, the regression formulas for both linear and multiple linear regression are given. In Table 2, we present the POC calculations based on chlorophyll $a$ and NLPOM.

The results in Table 2 clearly illustrate the problem which may occur when the classical regression method is used with organic carbon and chlorophyll as variables. In April and June, this approach would suggest a very high NLPOM contribution (more than $60 \%$ ): the multiple linear regression method, however, demonstrates that only a small part of this non-chlorophyll related carbon originates from the NLPOM. Looking at the 3 series together, one observes a decrease in NLPOM from April to November when chlorophyll a alone is used as an independent variable. This runs counter to what one should expect, viz. a gradual increase due to mortality of phytoplankton after the spring bloom. The multiple linear regression method, however, gives completely different results: here, we find an increase of the NLPOM beginning with $0.16 \%$ in April and ending with $26 \%$ in November. We find these results more acceptable. In June, and especially in April, on the other hand, there is a considerable amount of unexplained non-chlorophyll-related carbon. We assume that this carbon represents the mucous envelope of Phaeocystis colonies. P. pouchetii (Haptophyceae) is the dominant species in this zone and period. The size of the mucous envelope does not necessarily correlate with chlorophyll content, since strictly speaking the envelope is not a structural product of the Phaeocystis cells. Macro- and microzooplankton may also contribute to the bulk of nonchlorophyll-related carbon.

As to the November samples, the results of the new and traditional methods roughly overlap. We now find that NLPOM contributes almost all carbon which is not accounted for by chlorophyll $a$.

It may be concluded, then, that the classical regression method in some cases overestimates the NLPOM contribution. In general, therefore, it is advisable to obtain independent estimates of each of the different

Table 1 Regression formulas. POC in $\mathrm{mg} \mathrm{l}^{-1}$; chl $a$ in $\mathrm{mg} \mathrm{m}^{-3}$; NLPOM in $\mu \mathrm{m}^{2}\left(100 \mathrm{ml}^{-1}\right.$; $\mathrm{r}$ : correlation coefficient

\section{Apr 1983 \\ Linear regression \\ Multiple linear regression \\ Jun 1983 \\ Linear regression \\ Multiple linear regression}

\section{Nov 1983}

Linear regression

Multiple linear regression

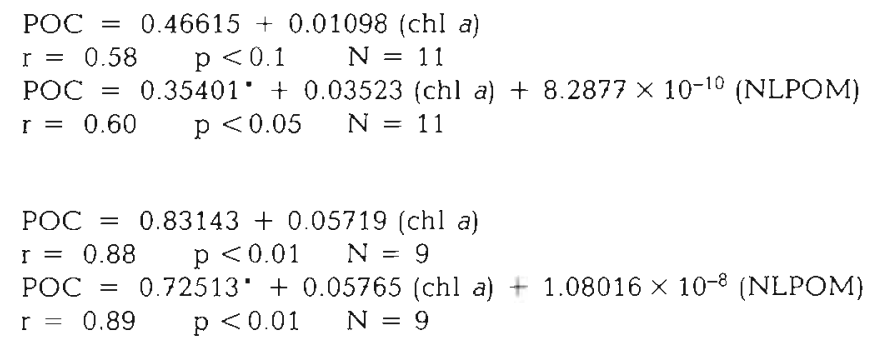

- Unexplained organic carbon 
Table 2. POC calculations

\begin{tabular}{|c|c|c|c|c|}
\hline & \multicolumn{2}{|c|}{$\begin{array}{l}\text { Linear regression } \\
\text { POC on chl a }\end{array}$} & \multicolumn{2}{|c|}{$\begin{array}{l}\text { Multiple linear regression } \\
\text { POC on chl } a \text { and NLPOM }\end{array}$} \\
\hline & $\mathrm{POC}\left(\mathrm{mg} \mathrm{l}^{-1}\right)$ & $\%$ & POC $\left(\mathrm{mg} \mathrm{I}^{-1}\right)$ & $\%$ \\
\hline \multicolumn{5}{|l|}{ Apr 1983} \\
\hline Calculated average phyto-C & 0.046 & 9.0 & 0.146 & 29.2 \\
\hline Calculated average NLPOM-C & 0.466 & 91.0 & 0.0008 & 0.16 \\
\hline Total POC & 0.512 & 100.0 & 0.501 & 100.0 \\
\hline Measured average total POC & 0.509 & & & \\
\hline Unexplained POC & - & - & 0.354 & 70.7 \\
\hline \multicolumn{5}{|l|}{ Jun 1983} \\
\hline Calculated average phyto-C & 0.423 & 33.7 & 0.426 & 34.4 \\
\hline Calculated average NLPOM-C & 0.831 & 66.3 & 0.072 & 5.8 \\
\hline Total POC & 1.254 & 100.0 & 1.240 & 100.0 \\
\hline Measured average total POC & 1.250 & & & \\
\hline Unexplained POC & - & - & 0.742 & 59.8 \\
\hline \multicolumn{5}{|l|}{ Nov 1983} \\
\hline Calculated average phyto-C & 0.293 & 54.9 & 0.304 & 57.0 \\
\hline Calculated average NLPOM-C & 0.241 & 45.1 & 0.139 & 26.0 \\
\hline Total POC & 0.534 & 100.0 & 0.534 & 100.0 \\
\hline Measured average total POC & 0.534 & & & \\
\hline Unexplained POC & - & - & 0.091 & 17.0 \\
\hline
\end{tabular}

classes of particles contributing to TPOC. This includes the zooplankton. The technique presented here allows a more accurate apportionment of nonliving versus living organic carbon. The method of multiple linear regression, on the other hand, serves to provide a quantitative estimate of the carbon content of the organic tripton. Of course, one must take account of the fact that the microscope produces only a 2-dimensional image of the particles. This can produce serious errors in NLPOM calculations, if the particles are heterogeneous in structure.

Acknowledgements. P. P. and M. B. are research assistants of the Belgian National Fund for Scientific Research (NFWO). We especially thank Mrs. Marcia Bogaert for the chlorophyll and carbon analyses.

\section{LITERATURE CITED}

Banse, K (1977). Determining the carbon-to-chlorophyll ratio of natural phytoplankton. Mar. Biol. 41: 199-212

Chan, A. T. (1978). Comparative physiological study of marine diatoms and dinoflagellates in relation to irradiance and cell size. 1. Growth under continuous light. J. Phycol. 14: 396-402

Gassmann, G., Gillbricht, M. (1982). Correlations between phytoplankton, organic detritus and carbon in North Sea waters during the Fladenground experiment (FLEX 76). Helgoländer Meeresunters. 35: 253-262

Hagmeier, E. (1961). Plankton-Äquivalente. Kieler Meeresforsch. Sonderheft 17: 32-47

Laws, E. A., Wong, D. C. L. (1978). Studies of carbon and nitrogen metabolism by three marine phytoplankton species in nitrate-limited continuous culture. J. Phycol. 14: $406-416$

Mel'nikov, N. A. (1976). Comparison of the magnitude of the microplankton biomass determined from ATP and by direct microscopy. Oceanology Acad. Sci. USSR. 16 (2): $181-183$

Phillips, H. J. (1973). Dye exclusion tests for cell viability. In: Kruse, P. F., Patterson, M. K., (ed.) Tissue culture. Academic Press, New York and London, p. 406-408

Strathmann, R. R. (1967). Estimating the organic carbon content of phytoplankton from cell volume or plasma volume. Limnol. Oceanogr. 12: 411-419

Strickland, J. D. H., Parsons, T. R. (1968). A practical handbook of seawater analysis. Bull. Fish. Res. Bd Can. 167

This paper was submitted to the editor; it was accepted for printing on June 3, 1985 